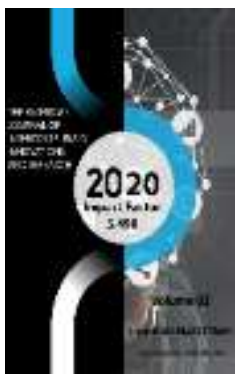

Journal Website: http://usajournalshub.c om/index,php/tajiir

Copyright: Original content from this work may be used under the terms of the creative commons attributes 4.0 licence.

\section{Innovative Pedogogical Technologies For Training The Course Of Physics}

\author{
Atoeva Mehriniso Farhodovna \\ Associate Professor Of The Department Of Physics, Bukhara State University, Uzbekistan \\ Arabov Jasur Olimboevich \\ Senior Lecturers Of The Department Of Physics, Bukhara State University, Uzbekistan \\ Kobilov Bakhtiyor Badriddinovich \\ Senior Lecturers Of The Department Of Physics, Bukhara State University, Uzbekistan
}

\title{
ABSTRACT
}

The article discusses the use of innovative technological methods in teaching physics, the combination of information technology, modern pedagogical technologies and interactive methods to improve the effectiveness of teaching. This article is intended for physics teachers, professionals, and students.

\section{KEYWORDS}

Information technology, interactive method, innovative pedagogical technologies, technological developments, laboratory, modern laboratory equipment.

\section{INTRODUCTION}

The task of modern education is not just to communicate knowledge or to turn knowledge into a tool for the creative development of the world, at the present stage of development of society, the requirements for the preservation and development of the student's personal qualities, the development of his creative potential and intellect, life value orientations come to the fore.

The question of how to purposefully develop the intellect of a student, his creative thinking, form a scientific worldview and an active life position, using special pedagogical means, remains open. This is the number one problem of modern innovative searches. 
In innovative processes, the goal of learning is to develop students' opportunities to master new experiences based on the formation of creative and critical thinking, to provide conditions for such development that would allow everyone to reveal and fully realize their potential: physical, spiritual and intellectual.

\section{MATERIALS AND METHODS}

Let's define the term innovation processes from a historical and scientific point of view:

An innovation is an implemented innovation that provides a qualitative increase in the efficiency of processes or products in demand by the market.

The term "innovation" comes from the Latin "novatio", which means "update" (or "change") and the prefix "in", which translates from Latin as "in the direction", if translated literally "Innovatio" - "in the direction of change" ... The very concept of innovation first appeared in scientific research in the 19th century. The concept of "innovation" received a new life at the beginning of the XX century. in the scientific works of the Austrian economist J. Schumpeter as a result of the analysis of "innovative combinations", changes in the development of economic systems.

Innovation is not just any innovation or innovation, but only one that seriously increases the efficiency of the current system.

Accordingly, it is necessary to clearly define and differentiate the concepts of "innovative educational technologies" and "innovative education". In this way:
Innovative educational technologies and programs are any educational technologies that are the result of the innovative activity of teachers who created and developed them;

Innovative education is only those innovative educational technologies and programs where the result of the innovative activity of teachers is the creation (generation) of innovative ideas by the students.

Innovation in education, understood in a broad sense as the introduction of a new, change, improvement and improvement of the existing one, can be called an immanent characteristic of education, arising from its basic meaning, essence and significance.

The main functions of the teacher's innovative activity include progressive (so-called defectfree) changes in the pedagogical process and its components:

1) Change in purpose;

2) Change in the content of education;

3) New teaching aids;

4) New ideas of education;

5) New ways and techniques of teaching, development, education of younger students, etc.

Depending on the area in which innovation processes take place, the following innovation processes can be distinguished:

1) In the content of education;

2) In technology;

3) In the organization;

4) In the system and management;

5) In educational ecology.

Innovative technologies for teaching physics (research, play, discussion, etc.) should include such types of student activities that are 
characterized by their subjective position in the lesson, since the activities of students in the lesson are determined not only by the content and structure of physical knowledge, but also by their individual needs and interests.

The methodology of using innovative technologies for teaching physics will be effective if they ensure the full inclusion of students in cognitive activities in the lesson, which involves independent receipt and analysis of results, an interactive form of organizing search activities, a positive emotional attitude of students to the content of the lesson and their orientation towards achieving success in educational activities.

The science of molecular physics studies the phenomena associated with the interaction and collective motion of a large number of particles (molecules, atoms) that make up macroscopic systems in various states of aggregation. Students should be familiar with the methods and models used in the study of this section of general physics, have theoretical and practical knowledge and skills sufficient for a successful assessment in their field in the future. 'Ladi. Advances in molecular physics have led to the development of various fields of science and technology, such as the explanation and study of atmospheric phenomena, the illumination of gas discharge processes, the field of vacuum and cryogenic technology, and biology with kosmosis and capillary action in living organisms. can be used in the study of related processes, in the production of compounds and alloys with various parameters, in thermodynamics, chemistry (gas laws), in the analysis of statistical processes and in many other areas.

\section{RESULTS AND DISCUSSIONS}

The following requirements apply to the knowledge, skills and abilities of students in the natural sciences. Student shoud know:

"Although the laws governing atoms and molecules are the laws of quantum mechanics, most of the properties of bodies are not related to the quantum nature of atoms and molecules, but to the fact that they contain an excessive amount of atoms and molecules. know the causes of surface tension forces and capillary phenomena on the surface of a liquid;

- To be able to calculate the parameters of the gas state for a given state, the change in the internal energy of the gas in various processes, the work done, the amount of heat received or transferred, the thermal signature of the gas corresponding to certain conditions, using the laws of an ideal gas and the equations of state of an ideal gas. be able to count and find their names;

- To know the number or proportion of gas molecules moving in a certain range of speeds, the reasons for migration in gases and liquids, the values of the migration coefficients, the average free path of molecules and migration, be able to know the values of the coefficients, which causes the difference between the states of an ideal and a real gas, calculate the state parameters real gas based on the knowledge gained;

- Be able to explain the basic laws of thermodynamics, the principle of operation of heat engines and their maximum efficiency, explain the causes of anisotropy in the phenomena of crystals, calculate the parameters of crystal unit 
cells, determine the planes and directions of crystals, the quantum theory of heat capacity of solids and have skills.
We will consider the use of modern technologies using the example of the plot of the movement of objects shot at an angle to the horizontal and relative to the horizon In the lectures.

The technological map of the course is presented in the following table:

\begin{tabular}{|c|c|c|}
\hline Subject & \multicolumn{2}{|c|}{$\begin{array}{c}\text { The movement of the object horizontally and at an angle to the } \\
\text { horizontal }\end{array}$} \\
\hline $\begin{array}{l}\text { Goal } \\
\text { objec }\end{array}$ & $\begin{array}{c}\text { For the teacher: } \\
\text {-Formation of the necessary knowledge on } \\
\text { the subject; } \\
\text {-Overview of technology and literature on the } \\
\text { topic; } \\
\text {-Increase student activity. }\end{array}$ & $\begin{array}{l}\text { For students: } \\
\text {-Get information on a new } \\
\text { topic; } \\
\text {-Explore new concepts on } \\
\text { the topic; } \\
\text {-Increase in self-activity. }\end{array}$ \\
\hline $\begin{array}{r}\text { Cor } \\
\operatorname{tr} \\
\mathrm{m}\end{array}$ & \multicolumn{2}{|c|}{$\begin{array}{l}\text { The movement of objects at an angle to the horizontal and to the } \\
\text { horizontal. Flight range, maximum climb balance, ascent time, flight time, } \\
\text { normal, tangential and full acceleration. The speed of an object at an } \\
\text { arbitrary moment in time, the radius of curvature of its trajectory, the } \\
\text { angle relative to the horizon. }\end{array}$} \\
\hline $\begin{array}{r}\text { Lea } \\
\text { techn }\end{array}$ & \multicolumn{2}{|c|}{$\begin{array}{c}\text { Forms: lecture, collective, pair; Methods: discussion of baxs, BBB, cluster; } \\
\text { Methods: explanation, speech technique; } \\
\text { Tools: multimedia, drawings, visual aids; Control: supervision, mutual } \\
\text { control; } \\
\text { Rating: rating. }\end{array}$} \\
\hline & $\begin{array}{c}\text { For the teacher: } \\
\text { Achieving the expected result, the formation } \\
\text { of the necessary knowledge on the subject, } \\
\text { to establish independent learning of }\end{array}$ & $\begin{array}{l}\text { For students: get the } \\
\text { necessary knowledge of } \\
\text { the subject, have a } \\
\text { complete understanding of } \\
\text { the movement of objects, } \\
\text { shot at an angle to the } \\
\text { horizon and to horizon, } \\
\text { understand the concepts. } \\
\text { study }\end{array}$ \\
\hline $\begin{array}{l}\text { Analyzing the } \\
\text { results and } \\
\text { making } \\
\text { changes }\end{array}$ & \multicolumn{2}{|c|}{$\begin{array}{c}\text { Search for new technologies for the next lesson, preparation of new } \\
\text { visual aids and materials, independent creative assignments, increasing } \\
\text { the activity of students. }\end{array}$} \\
\hline
\end{tabular}


It is advisable to organize the lesson according to the following plan:

1) The movement of an object shot at an angle to the horizon

2) Maximum lifting height

3) Flight range

4) Climb time and flight time

5) Radius of curvature
6) The movement of a horizontally shot object

7) Flight time

8) Flight range

9) Normal, tangential and full acceleration

Educational technologies improve the efficiency of solving physics problems.

Methods of preparing students for problem solving:

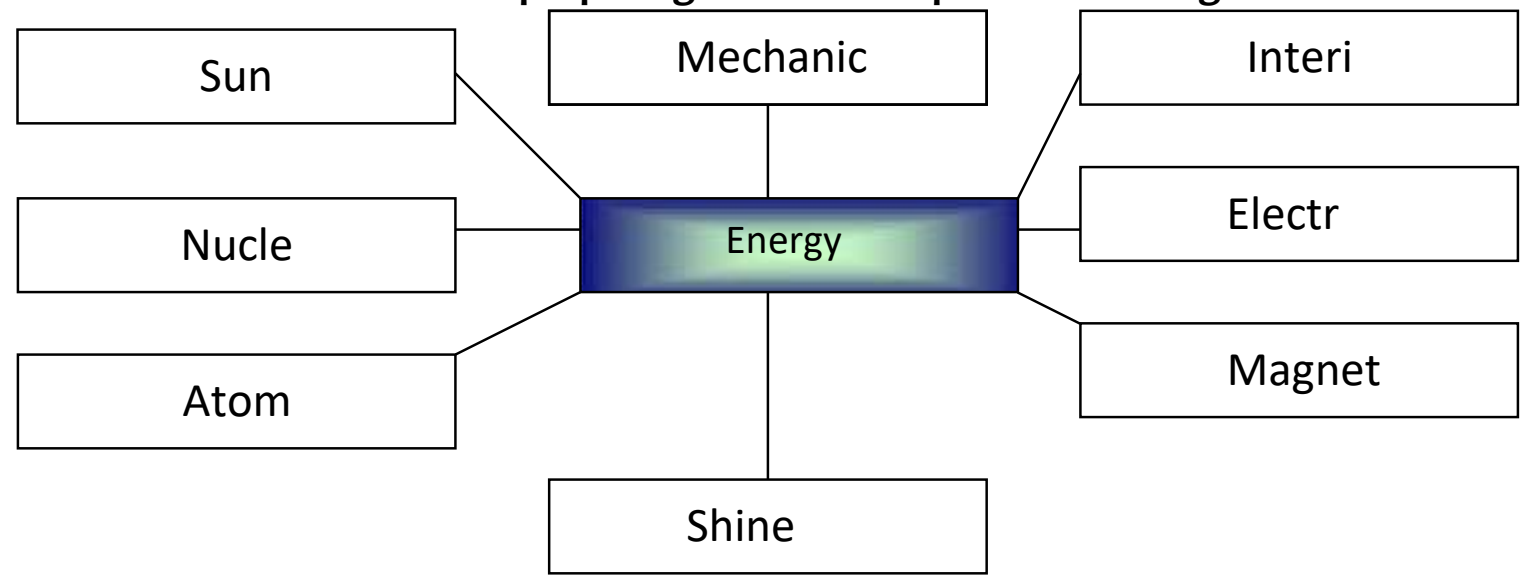

\section{Light energy}




\section{Below is a flow chart of a physics course on solving problems related to the law of} conservation of mechanical energy.

\begin{tabular}{|c|c|c|}
\hline 1. & Subject: & $\begin{array}{l}\text { Solving the problem on the topic "The Law of } \\
\text { Conservation of Mechanical Energy". }\end{array}$ \\
\hline 2. & $\begin{array}{c}\text { Goals, } \\
\text { objectives }\end{array}$ & $\begin{array}{l}\text { Explaining to students the goals and objectives of problem } \\
\text { solving. } \\
\text { Broader understanding of the practical meaning of the law } \\
\text { of conservation of energy. } \\
\text { Students will be able to master the handouts on the topic } \\
\text { individually and in groups, as well as control the level of } \\
\text { mastering the texts of the handouts through } \\
\text { conversational discussions. } \\
\text { Assessment of knowledge. }\end{array}$ \\
\hline 3. & $\begin{array}{r}\text { The con } \\
\text { the lea } \\
\text { proc }\end{array}$ & $\begin{array}{c}\text { Explaining to students the general aspects of problem } \\
\text { solving and the specifics of each topic. Enumeration of } \\
\text { algorithms for solving problems related to the law of } \\
\text { conservation of energy, as well as analyze each sequence } \\
\text { in the algorithm with students, draw conclusions. Solving } \\
\text { the problems in several ways and geting the same result. } \\
\text { Creatively adapt to the content of the problem in a new } \\
\text { context } \\
\text { arrange and work independently. }\end{array}$ \\
\hline 4. & $\begin{array}{c}\text { Technology of } \\
\text { implementation } \\
\text { of educational } \\
\text { process }\end{array}$ & $\begin{array}{l}\text { Method: oral presentation, conversation discussion. Form } \\
\text { "Networks" and "Computer technologies": practical } \\
\text { exercises in small groups and teams. } \\
\text { Tool: handouts, texts. } \\
\text { Method: drawings, computer slides. }\end{array}$ \\
\hline
\end{tabular}

Each lesson of the subject studied by the teacher, as well as the above flowchart for each lesson, allows him to present and understand the subject as a whole (for one semester, one academic year), the beginning of the entire educational process, helps them see the goal and the achieved result. In particular, the construction of a technological map, focused on the abilities and needs of the student, brings the teacher, as a person, to the center of learning. This improves the effectiveness of training.
Consideration of students as individuals in the learning process, the use of various pedagogical technologies and modern methods allows them to think independently, freely, creatively, responsibly, conduct research, analyze, effectively use scientific literature, and most importantly, enhances their interest in science and their chosen profession.

Achieving such a result requires the use of innovative technologies in practice, in the learning process. They are very different. Let's 
dwell on some of them. The modern methods presented in this article, as well as technological trainings that help increase the effectiveness of learning, help students develop the ability to form logical, intellectual, creative, critical, independent thinking, become competitive, mature professionals and develop the necessary professional qualities.

Technological map of laboratory works in physics.

\begin{tabular}{|c|c|}
\hline Subject: & $\begin{array}{c}\text { Determination of the focal length of the converging and } \\
\text { diffusing lenses. }\end{array}$ \\
\hline Objective Tasks & $\begin{array}{l}\text { Informing students about the types of lenses, their using, } \\
\text { about disadvantages and conducting experiments. } \\
\text { Study of methods for determining the focal lengths of } \\
\text { lenses, calculation of lens parameters. }\end{array}$ \\
\hline $\begin{array}{l}\text { Content of the } \\
\text { educational } \\
\text { process }\end{array}$ & $\begin{array}{l}\text { Lens. Lens type, basis of optical instruments, lens position in } \\
\text { microscopes. Formula for calculating the focal length of a } \\
\text { thin lens. The Methods for creating an image of an object on } \\
\text { collecting and diffusing lenses. }\end{array}$ \\
\hline $\begin{array}{c}\text { Technology of } \\
\text { implementatio } \\
\mathrm{n} \text { of } \\
\text { educational } \\
\text { process }\end{array}$ & $\begin{array}{c}\text { Method. Oral presentation. Conversation discussion. Form: } \\
\text { Laboratory. Working in groups and teams. } \\
\text { Medium: convex and concave lenses, light source and } \\
\text { object, optical base, screen, ruler and caliper. } \\
\text { Method: Based on finished devices and drawings. Control: } \\
\text { Verbal control. Calculation of results. Counting errors. Self- } \\
\text { control. } \\
\text { Evaluation: Based on a reward points system. } \\
\end{array}$ \\
\hline $\begin{array}{l}\text { Expected } \\
\text { results }\end{array}$ & \begin{tabular}{|} 
Teacher \\
Students will be able to cope with laboratory work in a short \\
period of time. Increases studencheskuyu activity. This \\
causes students to be interested in the lesson. At the same \\
time otsenivaetsya bolshinstvo studentov. They dostigayut \\
postavlennoy pered soboy tseli. \\
Student \\
Acquires new knowledge. Ustroystva razvivayut ability to \\
work with instruments. Nauchatsya works individually and in \\
groups. Conversation improves. Learn self-control. The \\
ability to remember increases. \\
Get a lot of information for a short period of time.
\end{tabular} \\
\hline
\end{tabular}




\begin{tabular}{|c|c|}
\hline Future plans & $\begin{array}{c}\text { Teacher } \\
\text { Working on yourself to apply methods and technologies to } \\
\text { engaging students in science in the classroom. Linking the } \\
\text { topic to everyday life and applying it to science and } \\
\text { technology. Improving pedagogical skills. } \\
\text { Student }\end{array}$ \\
$\begin{array}{c}\text { To learning to work independently with literature. Be able to } \\
\text { freely express your opinion. Computer observation and } \\
\text { results of materials related to this laboratory. Developing } \\
\text { the ability to come to a decision by analyzing your own } \\
\text { opinion and opinions }\end{array}$ \\
\hline
\end{tabular}

The procedure for carrying out laboratory work and reporting.

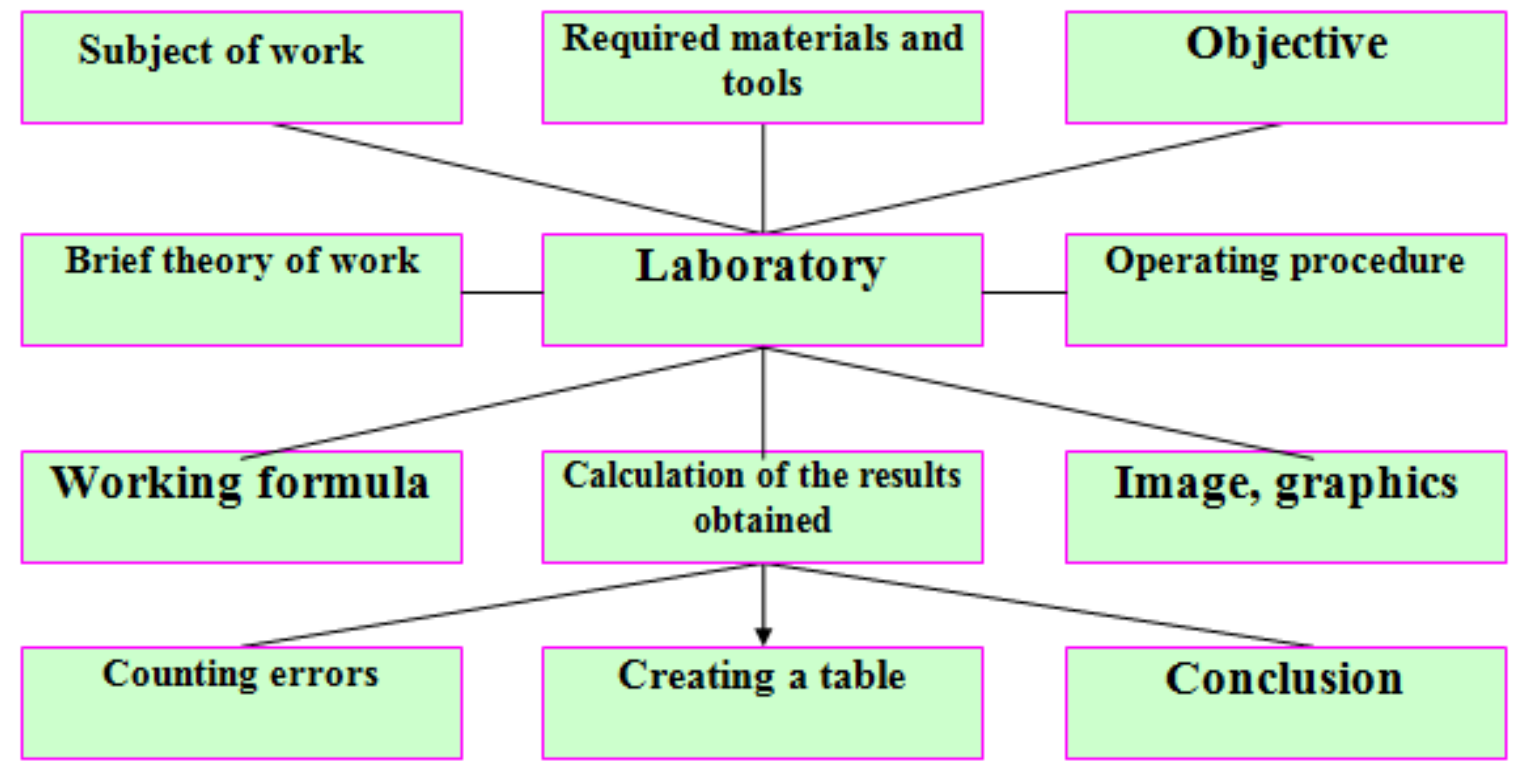

\section{CONCLUSION}

The use of modern technologies in education plays an important role in improving the quality of education. The implementation of the national curriculum requires improving the quality of education. In this regard, modern technologies penetrate into various fields of education.
Methods of applying modern technologies in the process of teaching physics were demonstrated. The use of modern technologies increases the activity of students and thereby stimulates them to acquire indepth knowledge. Also, the practical application of theoretical knowledge helps 
them develop skills, develop creativity and develop the ability to work independently. This, in turn, gives them the opportunity to use them in their future activities.

The use of modern technology in all types of lessons, including lectures, practical exercises and laboratory exercises, allows students to gain solid knowledge.

\section{REFERENCES}

1. NN Azizkhzhayeva "Pedagogical technology and pedagogical skills" T.2003 9.R.Zh. Ishmukhamedov "Ways to increase the efficiency of teaching through innovative technologies" 10.

A.Kaldybekova,

2. Khodjaev "Ways to increase students' cognitive activity" T.

3. T.Rizaev, B. Nurullayev "Methods of solving problems in physics" T. 2007.

4. Yu.P. Chernova Graduation qualification work "Composition of test tasks under the section" Electricity and electromagnetism "T. 2007.

5. AG Glazunov and others. " Methods of Physical Education in Secondary School " T., Teacher 2019.

6. F. Zikrillayev "Works in the field of Beruni physics" T. 2017.

7. M. Rakhmatullaev General Physics Course. Mechanics. T., Teacher, 1995.

8. U. Begimkulov, R. Yusupov, O. Rajabova Collection of laboratory works from optics T. TSPU, 2020.

9. Secondary Specialized Vocational Education General Education State Standards and Curricula, Tashkent, Sharq Publishing and Printing Company Joint Venture, 2014
10. AG Ganiev, AK Avlikulov, GA Alimardonova Textbook "Physics" Part 1, Academic Lyceum and Vocational Colleges. T.: Teacher, 2020.

11. Zorina L.Ya. Didactic foundations of the formation of systematic knowledge of high school students. M .: Pedagogy, 1978.

12. Mirzakhmedov BM Applied questions of physics in the system of secondary education. Tashkent: Teachers. 2020

1) 12.. M.F. Atoyeva. Interdisciplinary relations in physics course at specialized secondary education. The Way of Science. Volgograd, 2016. - №9 (31). - P.22-24.

13. M.F. Atoyeva. The significance of periodicity at teaching physics. The Way of Science. Volgograd, 2016. - № 10 (32). - P.62-64.

14. M.F. Atoyeva. Use of Periodicity in Teaching Physics. Eastern European Scientific Journal. - Düsseldorf-Germany, 2017. № 4. P. 35-39.

15. M.F. Atoyeva. Didactic foundations of intermedia relations in the training of university students. International Scientific Journal. Theoretical \& Applied Science. p-ISSN: 23084944 (print) e-ISSN: 2409-0085 (online). Year: 2020 Issue: 06 Volume: 86, P. 124.

16. M.F. Atoyeva, R. Safarova. Pedagogical integration as a means of forming professionally important qualities among students of a medical university. Academicia. ISSN: 2249-7137 Vol. 10, Issue 8, August 2020. Impact Factor: SJIF $2020=7.13$ ACADEMICIA: An International Multidisciplinary Research Journal https://saarj.comэ.

17. M.F. Atoyeva. Pedagogical Tests As An Element Of Types Of Pedagogical Technologies. The American Journal of Applied Sciences, 2(09), (TAJAS) SJIF-5.276 DOI-10.37547/tajas Volume 2 Issue 9, 
19.09.2020. ISSN 2689-09. 92 The USA Journals, USA www.usajournalshub.com/index.php/tajas 164-169. Имп.5.2.

18. Farkhodovna, A. M. (2020). The problems of preparing students for the use of school physical experiment in the context of specialized education at secondary schools. European Journal of Research and Reflection in Educational Sciences, 8 (9), 164-167.

19. H.O. Juraev. Ways of Using Educational Materials on Alternative Energy Sources at Physics Lessons. Eastern European Scientific Journal. -Düsseldorf, 2017. № 2. P. 83-86.

20. H.O. Juraev. Training Materials for Alternative Energy Sources in Education. Eastern European Scientific Journal. Düsseldorf,2017. №1. -P. 127-131.

21. H.O. Juraev., S.K.Kakhkhorov. Use of alternative energy sources at the natural sciences lessons.

22. H.O. Juraev., S.Q. Qahhorov. Modeling of heat-physical processes insolar dryers. Journal of Critical Reviews.-Malaysia, 2020.№ 7, ISSUE 17. 9-15 pp.

23. Saidov S.O., Fayzieva Kh. A., Yuldosheva N. B. The Elements Of Organization of The Educational Process On The Basis Of New Pedagogical Technologies. The American Journal of Applied Sciences, 2(09), (TAJAS) SJIF-5.276 DOI-10.37547/tajas Volume 2 Issue 9, 19.09.2020. ISSN 2689-09. 92 The USA Journals, USA www.usajournalshub.com/index.php/tajas 164-169. Имп.5.2. 